\title{
Breed and environmental factors influencing prevalence of helminths in sheep
}

Dafur, B. S ${ }^{1}$., Mbap, S. T ${ }^{2}$., Tok, C. C ${ }^{2}$. and Okoh, J. J. ${ }^{3}$

${ }^{\prime}$ Department of Animal Production, University of Jos

Department of Animal Production, Abubakar Tafawa Balewa University, Bauchi

${ }^{3}$ Department of Animal Science, Federal University Kashere

Corresponding author: bdafur70@gmail.com; 08036085311

\section{Abstract}

Gastrointestinal parasites impose severe constraints on sheep production worldwide. Information on prevalence of helminthosis in the ovine species could provide a useful guide towards effective control. Investigated in this study was helminthosis prevalence in some Nigerian sheep. The sheep included initial 64 yearlings (12 each of Balami, BL, and Uda, $U D$, and 20 each of Yankasa, YK and West African Dwarf, WAD, in a sex ratio of 1:1 per breed) and their 156 offspring. Faecal samples were collected from the sheep six-weekly over a period of 3 years and examined for the presence of various helminth species using the modified McMaster technique. Total helminths, Strongyles, Strongyloides, Moniezia, Trichuris and Nematodirus prevalence were 95.9, 87.3, 38.2, 60.6, 45.0 and 46.4\%, respectively. Based on prevalence, breeds and seasons ranked $(p<0.05)$ thus: $Y K=W A D>$ $B L>U D$ and late rainy $>$ early rainy $>$ late dry $>$ early dry. Females and older sheep $(\geq$ 4 months) had higher $(p<0.05)$ prevalence than males and lambs $(<4$ months $)$, respectively. Prevalence increased with decreased body condition score (BCS). Year, birth type and parity did not influence prevalence. It is concluded that there is high prevalence of helminthosis in the study area, with variation between breeds, sex, age groups and seasons. These variations could be exploited through selective breeding and cross breeding to control the disease with or without minimal use of anthelminthics.

Keywords: Sheep, Breeds, Environmental factors, Helminths, Prevalence

\section{Les Facteurs liés à la race et à l'environnement influençant la prévalence des helminthes chez les moutons}

Dafur, B. S ., Mbap, S. T²., Tok, C. C ${ }^{2}$. et Okoh, J. J. ${ }^{3}$

${ }^{1}$ Department of Animal Production, University of Jos

2 Department of Animal Production, Abubakar Tafawa Balewa University, Bauchi

${ }^{3}$ Department of Animal Science, Federal University Kashere
Corresponding author: bdafur70@gmail.com; 08036085311

\section{Résumé}

Les parasites gastro-intestinaux imposent de sévères contraintes à la production ovine dans le monde. Les informations sur la prévalence de l'helminthose chez les ovins pourraient fournir un guide utile pour une lutte efficace. La prévalence de l'helminthose chez certains moutons nigérians a été étudiée dans cette étude. Les moutons comprenaient au départ 64 yearlings (12 chacun de Balami, BL et Uda, UD, et 20 chacun de Yankasa, YK et West AfricanDwarf, WAD, dans un rapport de masculinité de $1: 1$ par race) et leurs 156 descendants. Des échantillons de matières fécales ont été prélevés sur les moutons six fois par semaine sur une période de 3 ans et examinés pour la présence de diverses espèces d'helminthes en utilisant la technique modifiée de McMaster. La prévalence totale des helminthes, Strongyles, Strongyloides, Moniezia, Trichuriset Nematodirus était de 95,9, 87,3, 38,2, 60, 6, 45,0 et 46,4\%, respectivement. Sur la base de la prévalence, des races et des saisons classées $(p<0,05)$ ainsi : YK $=W A D>B L>U D$ et pluvieux tardif $>$ pluvieux 


\section{Breed and environmental factors influencing prevalence of helminths in sheep}

précoce $>$ sec tardif $>$ sec tôt. Les femelles et les moutons plus âgés ( $\geq 4$ mois) avaient une prévalence plus élevée $(p<0,05)$ que les mâles et les agneaux $(<4$ mois $)$, respectivement. La prévalence augmentait avec la diminution du score de l'état corporel (le 'BCS'). L'année, le type de naissance et la parité n'ont pas influencé la prévalence. Il est conclu qu'il existe une prévalence élevée d'helminthose dans la zone d'étude, avec des variations entre les races, le sexe, les groupes d'âge et les saisons. Ces variations pourraient être exploitées par une sélection sélective et des croisements pour lutter contre la maladie avec ou sans utilisation minimale d'anthelminthiques.

Mots clés :mouton, races, facteurs environnementaux, helminthes, prévalence

\section{Introduction}

Sheep contribute $11 \%$ of the meat supplied from slaughter houses in the country and even more if rural unregistered slaughters are considered (Oni, 2002). They also play significant role in the nutrition, social and economic life of the people. They play specific roles at weddings and other festivities, and serve as regular source of cash income. The indigenous breeds of sheep of Nigeria in the order of importance are Yankasa $(60 \%)$, West African dwarf (WAD) (20\%), Uda (10\%) and Balami (10\%) (Ajala et al., 2008). Ages at first lambing are; 11-18, 11-18, 10-16 and 10-16 months, respectively. Lambing intervals are 227 days for Uda, Yankasa and West African dwarf and 282 days for Balami (Anonynous, 1990). The contribution of sheep to Nigeria's economy and their advantages over other farm animal species, cannot be over emphasized. However, optimum productivity is hampered by many constraints. These include nutritional, management, socio-economic, technical, institutional, genetic and disease constraints (Adegbola, 1998). Gastrointestinal nematodes impose severe economic constraints on sheep production in pastoral systems worldwide (Baker et al., 2004; Charon, 2004; Polott and Greeff, 2004). Losses occur through mortalities, reduced production due to subclinical parasitism and direct cost associated with control (Barger, 1982; ILCA, 1992). In the U.S. economic losses in ruminant due to parasites have been estimated at more than
\$3 billion per year (Smith, 2002). According to Kloosterman et al. (1992) up to $60 \%$ losses in sheep are due to parasites. In Nigeria, $11 \%$ loss of value of sheep and goat production was due to helminthosis (Schillhorn Van Veen, 1973). Akerejola et al. (1979) reported over U.S \$40 million annual loss in sheep and goat due to gastrointestinal nematode in Kano area alone. There have been many reports of variation among sheep breeds in resistance to internal parasites (Knight et al., 1973; Preston and Allonby, 1978, 1979a; Courtney et al.,1984; Gray, 1991; Orokpo, 1991; Gamble and Zajac, 1992; Chiroma, 1996, Dafur et al., 2008a, b; Biu et al., 2009). These reports except Orokpo (1991), Chiroma (1996) and Dafur et al. (2008a) are on non-Nigerian breeds of sheep. Information on differences among Nigerian sheep breeds is therefore scanty. The aim of this study was to evaluate the effect of breeds, sex, age, parity, birth type, year and season on sheep helminthosis prevalence.

\section{Materials and methods \\ Location and climate}

The research was carried out in Pankshin town, Jos Plateau. The Jos Plateau has been described by PADP (2000), WWF (2001) and Plateau State Government Organization (2004). It is a pear-shaped upland located in the middle of Nigeria between latitude $8^{\circ}$ and $10^{\circ}$ north and longitudes $7^{\circ}$ and $11^{\circ}$ east, at an average attitude of $1,200 \mathrm{~m}$ above sea level and reaches the highest peak in the Shere Hills 


\section{Dafur, Mbap, Tok and Okoh}

where it stands at $1,766 \mathrm{~m}$.

\section{Experimental animals}

The research commenced with a stock of 64 yearling sheep which comprised 12 each of Uda and Balami and 20 each of West African dwarf(WAD) and Yankasa in a sex ratio 1: 1 per breed. The Uda and Balami were bought from Railway market in Bauchi, North Eastern Nigeria while the Yankasa and WAD were sourced from local farmers and markets within Plateau State. The animals were quarantined and acclimatized for 2 months. Later, 156 offspring of the starting stock produced from controlled breeding (only within breed mating) were included.

\section{Sheep management}

Before purchase from farmers, sheep were managed under the traditional free-range in the dry season. In the rainy season when arable crops were growing, animals were kept under semi-intensive management. Under this system, sheep were taken out for grazing by a shepherd from late morning till evening. At the research station, sheep were housed in pens constructed with concrete blocks, floored and roofed with corrugated iron sheets. The females and a breeding ram of the same breed were kept together and all other males were collectively housed. Few days to lambing pregnant ewes were isolated and housed in a well littered lambing pen. After lambing, all necessary cleaning and identification processes were observed. New born lambs were kept with their ewes under close observation for 24 hours to ensure that they were suckled with colostrums. Ewes were allowed to graze without their lambs after 3 weeks of lambing. Throughout the period of the experimental study animals were grazed on locally available pasture from 9:00am to 5:00pm. Crop residues such as legumes and corn stalks, leafy shrubs and herbs were made available. In the evening they were returned to the pen and provided with salt lick and supplementary maize offals, groundnut haulm, cowpea and corn husks. Drinking water was supplied ad libitum. Before the start of experiment, animals were dewormed twice at monthly intervals with levamisole and albendazole at dose rates of 7.5 and $5.0 \mathrm{mg} / \mathrm{kg}$ body weight respectively and no deworming thereafter. Asuntol solution bath was carried out at quarterly intervals to control ectoparasites. Prophylactic treatment with oxytetracycline long acting (LA) was undertaken twice a year to prevent bacterial infections.

\section{Faecal sample collection and analysis}

Faecal samples were collected directly from the rectum and sometimes as the animals defaecated using clean polythene bags. The collection was carried out 6-weekly. Samples were properly labelled with a masking tape showing breed, age, sex, date of collection and body conformation score. They were then stored at $4^{\circ} \mathrm{C}$ until examination within three days. Faecal samples were examined for the presence of eggs of various helminth species and faecal egg counts (FEC), measured as number of eggs per gramme of faeces (epg). It was determined using the modified McMaster technique (Urquhart et al., 1996; Kassai, 1999). Worm eggs were identified as described as Alrifai (2010).

\section{Body condition scores}

The body condition scores (BCS) were assessed by combining palpation of the sheep in the lumber region and around the backbone in the loin area immediately behind the last rib, as suggested by Boden (1991) and the guidelines. The scores used in the study were 1.0, 2.0, 3.0, 4.0 and 5.0 for emaciated, thin, average, fat and obese respectively. Cases which did not fit these categories properly, i.e fell between whole numbers were assigned half scores as recommended by Thompson and Meyer (1994) and additional scores of 1.5, 2.5 and 3.5 were therefore used. 


\section{Breed and environmental factors influencing prevalence of helminths in sheep}

Age, parity, birth type and season

The ages of the starting stock were determined using the dentition procedure as described by Sastry and Thomas (1980) and information from sheep owners. Subsequently, ages of offspring were determined using birth records. Sheep were categorized into two age groups namely; young $(0-4$ months $)$ and matured (weaning and above). Parity was determined as number of times a dam had lambed. Birth type indicated the number of lambs per parturition (single, twins or triplets). Seasons were categorized as early dry (October - December), late dry (January - March), early rainy (April - June) and late rainy (July - September).

\section{Statistical analysis}

Chi-square test was carried out on the effects of breed, sex, year, season, BCS, parity, birth type and age on helminth prevalence in accordance with Steel and Torrie (1980).

The linear model used is as follows:

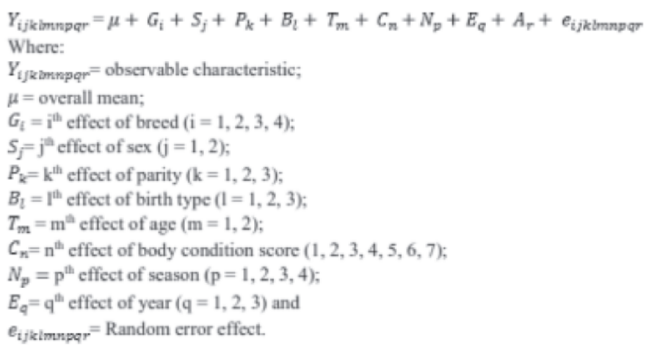

\section{Results}

The prevalence of infection with total helminth species (all helminths taken together), Strongyles, Strongyloides, Trichuris, Moniezia and Nematodirus by sheep breed, sex, age, body condition score (BCS), birth type, parity, season and year are depicted in Tables 1, 2, 3, 4, 5 and 6, respectively.

\section{All helminth species}

In Table 1, 95.9\% of the experimental sheep were infected with total helminth species. There was significant $(\mathrm{p}<0.05)$ difference in prevalence among breeds. The highest prevalence was observed in Yankasa (98.6\%), and West African dwarf (WAD) $(98.4 \%)$, followed by Balami $(92.5 \%)$ while Uda $(91.3 \%)$ had the lowest. Similarly, there was higher $(p<0.05)$ prevalence in females than males and in adult sheep than lambs with respective values of 98.3 and $93.3 \%$, and 98.5 and $89.8 \%$. Prevalence was higher $(\mathrm{P}<0.01)$ in sheep with low BCS as compared to those with high values. The animals with BCS $1.0-2.0$ were $100 \%$ infected while only $66 \%$ of the ones with BCS 4.0 were infected. Birth type and lamb parity had no significant influence on prevalence. The ranges were $91.7 \%$ in singles to $100 \%$ in triplets and $94.4 \%$ in animals born at third parity to $97.2 \%$ for their second parity counterparts. Similarly, prevalences were 97.1, 94.7 and $96.0 \%$ in the first, second and third years respectively and did not differ significantly. Prevalences of 98.2, 98.2, 96.4 and $92.7 \%$ in late rainy, early rainy, late dry and early dry seasons respectively differed significantly $(\mathrm{p}<0.05)$ indicating the influence of season.

\section{Strongyles prevalence}

As shown in Table 2, infection with Strongyles was observed in $87.3 \%$ of the experimental sheep. Significant $(\mathrm{p}<0.05)$ effect of breed on prevalence was observed; West African dwarf ranked highest followed by Yankasa, Balami, while Uda was lowest with respective values of 93.4, 93.2, 80.0 and $78.3 \%$. similarly, prevalence was higher $(\mathrm{p}<0.01)$ in females $(92.2 \%)$ than males $(81.7 \%)$ and in adults $(95.4 \%)$ than lambs (87.2\%). Respective early rainy, late rainy, early dry and late dry seasons values of $92.7,90.9,83.6$ and $81.8 \%$ varied significantly $(\mathrm{p}<0.05)$. Yearly prevalences of $87.1,86.7$ and $68.0 \%$ in the first, second and third years respectively did not differ significantly.

Animals with lower BCS (1.0-2.0) were 


\section{Dafur, Mbap, Tok and Okoh}

Table 1: Prevalence of total helminths (overall) by sheep breed and environmental factors

\begin{tabular}{|c|c|c|c|c|c|c|}
\hline & \multirow{2}{*}{$\begin{array}{l}\text { Total } \\
\mathrm{N}\end{array}$} & \multicolumn{2}{|c|}{ Non-Infected } & \multicolumn{2}{|c|}{ Infected } & \multirow[t]{2}{*}{$\mathrm{X}^{2}$} \\
\hline & & No & $\%$ & No & $\%$ & \\
\hline Overall & 220 & 09 & 04.1 & 211 & 95.9 & \\
\hline \multicolumn{7}{|l|}{ Breed } \\
\hline Balami & 40 & 03 & 07.5 & 37 & 92.5 & \multirow{4}{*}{$5.362 * \mathrm{df}_{3}$} \\
\hline Uda & 46 & 04 & 08.7 & 42 & 91.3 & \\
\hline WAD & 61 & 01 & 01.6 & 60 & 98.4 & \\
\hline Yankasa & 73 & 01 & 01.4 & 72 & 98.6 & \\
\hline \multicolumn{7}{|l|}{ Sex } \\
\hline Male & 104 & 07 & 06.7 & 97 & 93.3 & \multirow[b]{2}{*}{$12.176 * \mathrm{df}_{1}$} \\
\hline Female & 116 & 02 & 01.7 & 114 & 98.3 & \\
\hline \multicolumn{7}{|l|}{ Age (Months) } \\
\hline $0-4$ & 156 & 16 & 10.2 & 140 & 89.8 & \multirow[b]{2}{*}{$14.333 * \mathrm{df}_{1}$} \\
\hline$>4$ & 64 & 01 & 1.5 & 63 & 98.5 & \\
\hline \multicolumn{7}{|l|}{ Season } \\
\hline Early dry & 55 & 02 & 03.6 & 53 & 96.4 & \multirow{4}{*}{$21.670 * \mathrm{df}_{3}$} \\
\hline Late dry & 55 & 04 & 07.3 & 51 & 92.7 & \\
\hline Early rainy & 55 & 01 & 01.8 & 54 & 98.2 & \\
\hline Late rainy & 55 & 01 & 01.8 & 54 & 98.2 & \\
\hline \multicolumn{7}{|l|}{ Year } \\
\hline First & 70 & 02 & 02.9 & 68 & 97.1 & \multirow{3}{*}{$3.016^{\mathrm{ns}} \mathrm{df}_{2}$} \\
\hline Second & 75 & 04 & 05.3 & 71 & 94.7 & \\
\hline Third & 75 & 03 & 04.0 & 72 & 96.0 & \\
\hline \multicolumn{7}{|l|}{ BCS } \\
\hline 1.0 & 03 & 00 & 00.0 & 03 & 100 & \multirow{7}{*}{$56.343 * * * \mathrm{df}_{6}$} \\
\hline 1.5 & 09 & 00 & 00.0 & 09 & 100 & \\
\hline 2.0 & 32 & 00 & 00.0 & 32 & 100 & \\
\hline 2.5 & 76 & 02 & 02.6 & 74 & 97.4 & \\
\hline 3.0 & 77 & 03 & 03.9 & 74 & 96.1 & \\
\hline 3.5 & 20 & 03 & 15.0 & 17 & 85.0 & \\
\hline 4.0 & 03 & 01 & 33.3 & 02 & 66.7 & \\
\hline \multicolumn{7}{|l|}{ Birth type } \\
\hline Single & 94 & 04 & 04.3 & 90 & 95.7 & \multirow{3}{*}{$2.922^{\mathrm{ns}} \mathrm{df}_{2}$} \\
\hline Twins & 57 & 02 & 03.5 & 55 & 96.5 & \\
\hline Triplet & 05 & 00 & 00.0 & 05 & 100.0 & \\
\hline \multicolumn{7}{|l|}{ Parity } \\
\hline $1^{\text {st }}$ & 67 & 03 & 04.5 & 64 & 95.5 & \multirow{3}{*}{$3.031^{\mathrm{ns}} \mathrm{df}_{2}$} \\
\hline $2^{\text {nd }}$ & 71 & 02 & 02.8 & 69 & 97.2 & \\
\hline $3^{\text {rd }}$ & 18 & 01 & 05.6 & 19 & 94.4 & \\
\hline
\end{tabular}

significantly $(\mathrm{p}<0.001)$ more infected than the ones with higher BCS with respective values of $86.8,84.4,75.0$ and $33.3 \%$ for 2.5 , 3.0, 3.5 and 4.0. Birth type did not affect prevalence with respective values of 87.2 ,
87.7 and $80.0 \%$ for singles, twins and triplets. Similarly, lamb's parity with respective prevalence values of 88.1, 85.9 and $88.1 \%$ in first, second and third did not affect prevalence. 
Breed and environmental factors influencing prevalence of helminths in sheep

Table 2: Prevalence of Strongyles by sheep breed and environmental factors

\begin{tabular}{|c|c|c|c|c|c|c|}
\hline & \multirow{2}{*}{$\begin{array}{l}\text { Total } \\
(\mathrm{N})\end{array}$} & \multicolumn{2}{|c|}{ Non-Infected } & \multicolumn{2}{|c|}{ Infected } & \multirow[t]{2}{*}{$\mathrm{X}^{2}$} \\
\hline & & No & $\%$ & No & $\%$ & \\
\hline Overall & 220 & 28 & 12.7 & 192 & 87.3 & \\
\hline \multicolumn{7}{|l|}{ Breed } \\
\hline Balami & 40 & 08 & 20.0 & 32 & 80.0 & \multirow{4}{*}{$7.316 * \mathrm{df}_{3}$} \\
\hline Uda & 46 & 10 & 21.7 & 36 & 78.3 & \\
\hline WAD & 61 & 04 & 6.6 & 57 & 93.4 & \\
\hline Yankasa & 73 & 05 & 6.8 & 68 & 93.2 & \\
\hline \multicolumn{7}{|l|}{ Sex } \\
\hline Male & 104 & 19 & 18.3 & 85 & 81.7 & \multirow[b]{2}{*}{$13.176^{* *} \mathrm{df}_{1}$} \\
\hline Female & 116 & 09 & 7.8 & 107 & 92.2 & \\
\hline \multicolumn{7}{|l|}{ Age (Months) } \\
\hline $0-4$ & 156 & 20 & 12.8 & 136 & 87.2 & \multirow[b]{2}{*}{$12.272 * * \mathrm{df}_{1}$} \\
\hline$>4$ & 64 & 03 & 4.6 & 61 & 95.4 & \\
\hline \multicolumn{7}{|l|}{ Season } \\
\hline Early dry & 55 & 09 & 16.4 & 46 & 83.6 & \multirow{4}{*}{$24.472 * \mathrm{df}_{3}$} \\
\hline Late dry & 55 & 10 & 18.2 & 45 & 81.8 & \\
\hline Early rainy & 55 & 04 & 7.3 & 51 & 92.7 & \\
\hline Late rainy & 55 & 05 & 9.1 & 50 & 90.9 & \\
\hline \multicolumn{7}{|l|}{ Year } \\
\hline First & 70 & 09 & 12.9 & 61 & 87.1 & \multirow{3}{*}{$2.670^{\mathrm{ns}} \mathrm{df}_{2}$} \\
\hline Second & 75 & 09 & 12.0 & 66 & 68.0 & \\
\hline Third & 75 & 10 & 13.3 & 65 & 86.7 & \\
\hline \multicolumn{7}{|l|}{ BCS } \\
\hline 1.0 & 03 & 00 & 0 & 03 & 100 & \multirow{7}{*}{$65.480 * * * \mathrm{df}_{5}$} \\
\hline 1.5 & 09 & 00 & 0 & 07 & 100 & \\
\hline 2.0 & 32 & 00 & 0 & 32 & 100 & \\
\hline 2.5 & 76 & 10 & 13.2 & 66 & 86.8 & \\
\hline 3.0 & 77 & 12 & 15.6 & 65 & 84.4 & \\
\hline 3.5 & 20 & 05 & 25.0 & 15 & 75.0 & \\
\hline 4.0 & 03 & 02 & 66.7 & 01 & 33.3 & \\
\hline \multicolumn{7}{|l|}{ Birth type } \\
\hline Single & 94 & 12 & 12.8 & 82 & 87.2 & \multirow{3}{*}{$1.730^{\mathrm{ns}} \mathrm{df}_{2}$} \\
\hline Twins & 57 & 07 & 12.3 & 50 & 87.7 & \\
\hline Triplet & 05 & 01 & 20.0 & 04 & 80.0 & \\
\hline \multicolumn{7}{|l|}{ Parity } \\
\hline $1^{\text {st }}$ & 67 & 08 & 11.9 & 59 & 88.1 & \multirow{3}{*}{$2.076^{\mathrm{ns}} \mathrm{df}_{2}$} \\
\hline $2^{\text {nd }}$ & 71 & 10 & 14.1 & 61 & 85.9 & \\
\hline $3 \mathrm{rd}$ & 18 & 02 & 11.1 & 16 & 88.1 & \\
\hline
\end{tabular}

\section{Strongyloides prevalence}

Strongyloides infected $38.2 \%$ of the experimental sheep. Significant $(\mathrm{p}<0.001)$ sheep breed effect was observed on strongyloides prevalence. The highest prevalence of $47.5 \%$ was observed in WAD, followed by Yankasa, $43.8 \%$, Uda, $28.3 \%$ while Balami was least $25.0 \%$. There was significant $(\mathrm{p}<0.05)$ influence of sheep sex on prevalence with a rate of $33.7 \%$ in males and $42.2 \%$ in females. Adult sheep had higher prevalence of
$70.3 \%$ than lambs, with $48.0 \%$. Season also had significant $(\mathrm{p}<0.01)$ influence on prevalence. The highest was observed in the early rainy season $54.5 \%$ followed by late rainy season, $43.6 \%$, late dry, $29.1 \%$ while the early dry had the lowest prevalence of $25.5 \%$. The yearly prevalence rates of 40.0 , 36.0 and 38.7 in the first, second and third years respectively did not significantly differ.

Body condition score significantly $(p<0.01)$ influenced prevalence with the highest 
Dafur, Mbap, Tok and Okoh

value $(100 \%)$ observed in animals with BCS 4.0. Lamb's birth type had significant $(\mathrm{p}<0.05)$ influence on prevalence with twins $(52.6 \%)$ being more infected than singles $(45.7 \%)$ and triplets (40.0\%). Lamb's parity with respective values of 46.3, 49.3 and $50.0 \%$ for first, second and third had no significant influence on prevalence.

Table 3: Prevalence of Strongyloides by sheep breed and environmental factors

\begin{tabular}{|c|c|c|c|c|c|c|}
\hline & \multirow{2}{*}{$\begin{array}{l}\text { Total } \\
\text { (N) }\end{array}$} & \multicolumn{2}{|c|}{ Non-Infected } & \multicolumn{2}{|c|}{ Infected } & \multirow[t]{2}{*}{$\mathrm{X}^{2}$} \\
\hline & & No & $\%$ & No & $\%$ & \\
\hline Overall & 220 & 136 & 61.8 & 84 & 38.2 & \\
\hline \multicolumn{7}{|l|}{ Breed } \\
\hline Balami & 40 & 30 & 75.0 & 10 & 25.0 & \multirow{4}{*}{$10.412 * * * \mathrm{df}_{3}$} \\
\hline Uda & 46 & 33 & 76.7 & 13 & 28.3 & \\
\hline WAD & 51 & 32 & 52.5 & 29 & 47.5 & \\
\hline Yankasa & 73 & 41 & 56.2 & 32 & 43.8 & \\
\hline \multicolumn{7}{|l|}{ Sex } \\
\hline Male & 104 & 69 & 66.3 & 35 & 33.7 & \multirow[b]{2}{*}{$12.272 * \mathrm{df}_{1}$} \\
\hline Female & 116 & 67 & 57.8 & 49 & 42.2 & \\
\hline \multicolumn{7}{|l|}{ Age (Months) } \\
\hline $0-4$ & 156 & 81 & 52.0 & 75 & 48.0 & \multirow[b]{2}{*}{$13.928 * * * \mathrm{df}_{2}$} \\
\hline$>4$ & 64 & 19 & 29.7 & 45 & 70.3 & \\
\hline \multicolumn{7}{|l|}{ Season } \\
\hline Early dry & 55 & 41 & 74.5 & 14 & 25.5 & \multirow{4}{*}{$20.892 * * \mathrm{df}_{3}$} \\
\hline Late dry & 55 & 39 & 70.9 & 16 & 29.1 & \\
\hline Early rainy & 55 & 25 & 45.5 & 30 & 54.5 & \\
\hline Late rainy & 55 & 31 & 56.4 & 24 & 43.6 & \\
\hline \multicolumn{7}{|l|}{ Year } \\
\hline First & 70 & 42 & 60.0 & 28 & 40.0 & \multirow{3}{*}{$2.982^{\mathrm{ns}} \mathrm{df}_{2}$} \\
\hline Second & 75 & 48 & 64.0 & 27 & 36.0 & \\
\hline Third & 75 & 46 & 61.3 & 29 & 38.7 & \\
\hline \multicolumn{7}{|l|}{ BCS } \\
\hline 1.0 & 03 & 00 & 00.0 & 03 & 100 & \multirow{7}{*}{$47.932 * * \mathrm{df}_{6}$} \\
\hline 1.5 & 09 & 00 & 00.0 & 09 & 100 & \\
\hline 2.0 & 32 & 04 & 12.5 & 28 & 87.5 & \\
\hline 2.5 & 76 & 56 & 73.3 & 20 & 22.7 & \\
\hline 3.0 & 77 & 58 & 75.3 & 19 & 24.7 & \\
\hline 3.5 & 20 & 15 & 75.0 & 05 & 25.0 & \\
\hline 4.0 & 03 & 03 & 100.0 & 00 & 00.00 & \\
\hline \multicolumn{7}{|l|}{ Birth type } \\
\hline Single & 94 & 51 & 54.3 & 43 & 45.7 & \multirow{3}{*}{$7.323 * \mathrm{df}_{2}$} \\
\hline Twins & 57 & 27 & 47.4 & 30 & 52.6 & \\
\hline Triplet & 05 & 03 & 60.0 & 02 & 40.0 & \\
\hline \multicolumn{7}{|l|}{ Parity } \\
\hline $1^{\text {st }}$ & 67 & 36 & 53.7 & 31 & 46.3 & \multirow{3}{*}{$4.00^{\mathrm{ns}} \mathrm{df}_{2}$} \\
\hline $2^{\text {nd }}$ & 71 & 36 & 50.7 & 35 & 49.3 & \\
\hline $3^{\text {rd }}$ & 18 & 09 & 50.0 & 09 & 50.0 & \\
\hline
\end{tabular}

\section{Moniezia prevalence}

The overall Moniezia prevalence in the experimental sheep population was $60.0 \%$. significant $(\mathrm{p}<0.01)$ influence of breed was observed. The WAD had the highest prevalence rate of $66.7 \%$ followed by
Yankasa with $65.8 \%$ while Balami and Uda were least with $50.0 \%$ each. Similarly, sex had significant $(p<0.05)$ influence with females exhibiting higher prevalence rate of $69.8 \%$ than males, $49.0 \%$. Age, in addition significantly $(\mathrm{p}<0.001)$ influenced 


\section{Breed and environmental factors influencing prevalence of helminths in sheep}

prevalence. Adult had higher prevalence rate of $89.1 \%$ than young lambs with $49.4 \%$. Furthermore, season significantly $(\mathrm{p}<0.01)$ influenced prevalence with respective values of $70.9,67.3,56.4$ and $45.5 \%$ in late rainy, early rainy, late dry and early dry. On the other hand, year did not influence prevalence as the prevalence rates of $62.9,57.3$ and $60.0 \%$ in the first, second and third years respectively did not significantly differ. Body condition score had significant influence on prevalence.
The highest prevalence of $100 \%$ each was observed in animals with BCS 1.0 and 1.5 while the lowest $(0.0 \%)$ was observed in BCS 4.0. Similarly, lamb's birth type significantly $(\mathrm{p}<0.05) \quad$ influence prevalence. Triplets had the highest prevalence rate of $60.0 \%$ followed by twins with $50.1 \%$ while singles had the lowest rate of $47.9 \%$. Parity did not significantly influence prevalence. The prevalence rates were $50.7,49.3$ and $50.7 \%$ respectively for first, second and third.

Table 4: Prevalence of Moniezia by sheep breed and environmental factors

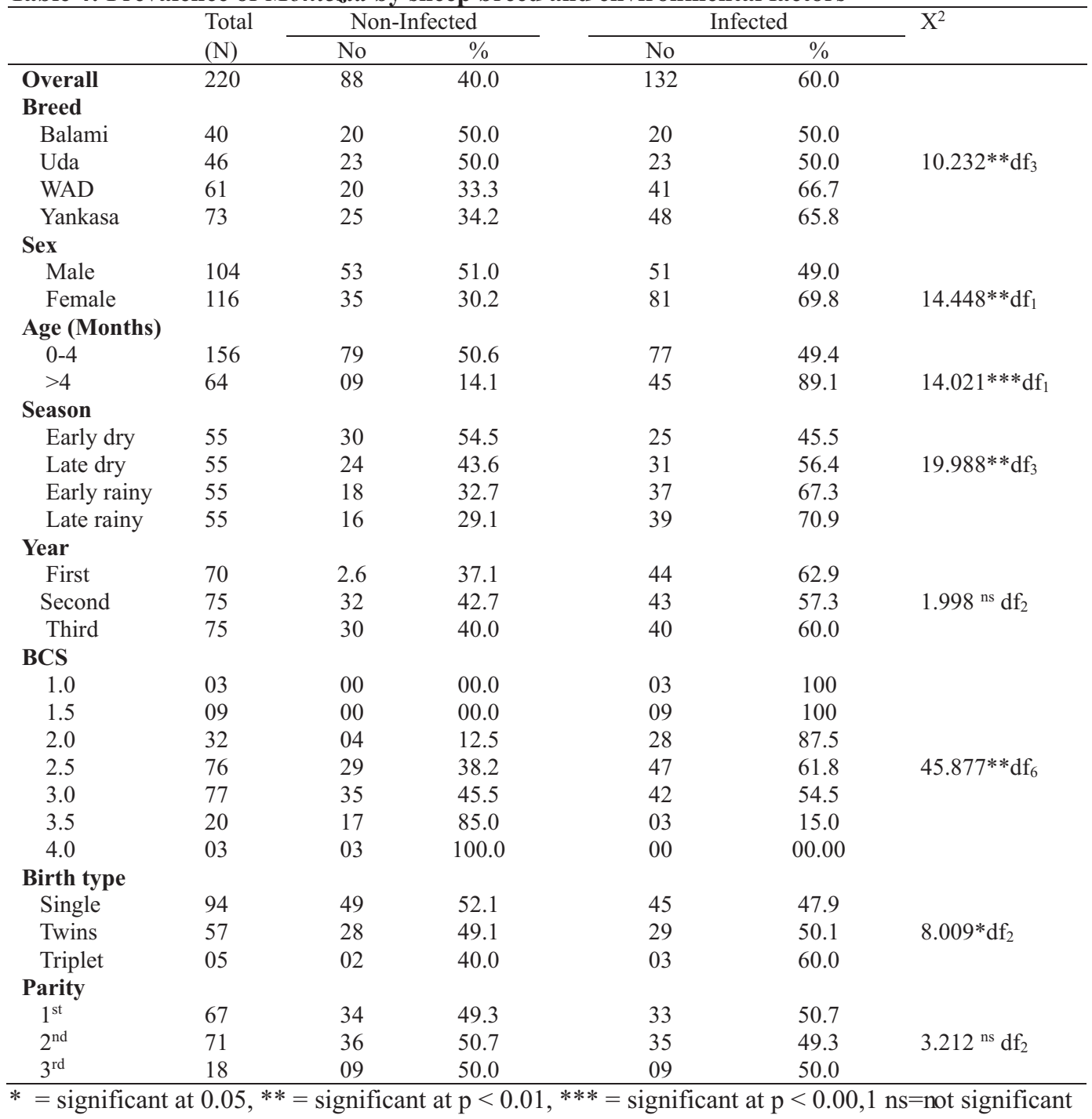




\section{Dafur, Mbap, Tok and Okoh}

\section{Trichuris prevalence}

The overall prevalence of Trichuris in the study population was $45.0 \%$. Sheep breed effect on prevalence was significant $(p<0.001)$. The highest prevalence rate of $56.2 \%$ was observed in Yankasa, followed closely by WAD with $55.7 \%$, Uda, $30.4 \%$ and lowest $(25.0 \%)$ in Balami. Significant $(p<0.01)$ influence of sex was also observed. Males had higher prevalence of $32.7 \%$ than females with $20.3 \%$. Similarly, age significantly $(p<0.001)$ influenced prevalence. There was higher prevalence, $65.6 \%$ in adult sheep than lambs, $36.5 \%$. Significant $(\mathrm{p}<0.01)$ influence of season on prevalence was observed. The highest prevalence $(61.8 \%)$ was in early rainy, followed by late rainy, $56.4 \%$, late dry, $44.0 \%$ while the lowest value of $38.2 \%$ was observed in the early dry season. Year did not significantly influence prevalence. The respective yearly prevalence rates were $47.1,45.3$ and $42.7 \%$ in the first, second and third.

Body condition scores had significant effect $(p<0.001)$ on prevalence. The highest prevalence $(66.7 \%)$ was observed in animals with BCS 1.0 while the lowest $(33.3 \%)$ was in BCS 4.0. Lamb's birth type and parity did not significantly influence prevalence. Prevalence rates were 35.1, 38.6 and $40.0 \%$ in singles, twins and triplets; and 35.8, 35.2 and $44.4 \%$ in first, second and third parities, respectively.

Table 5: Prevalence of Trichuris by sheep breed and environmental factors

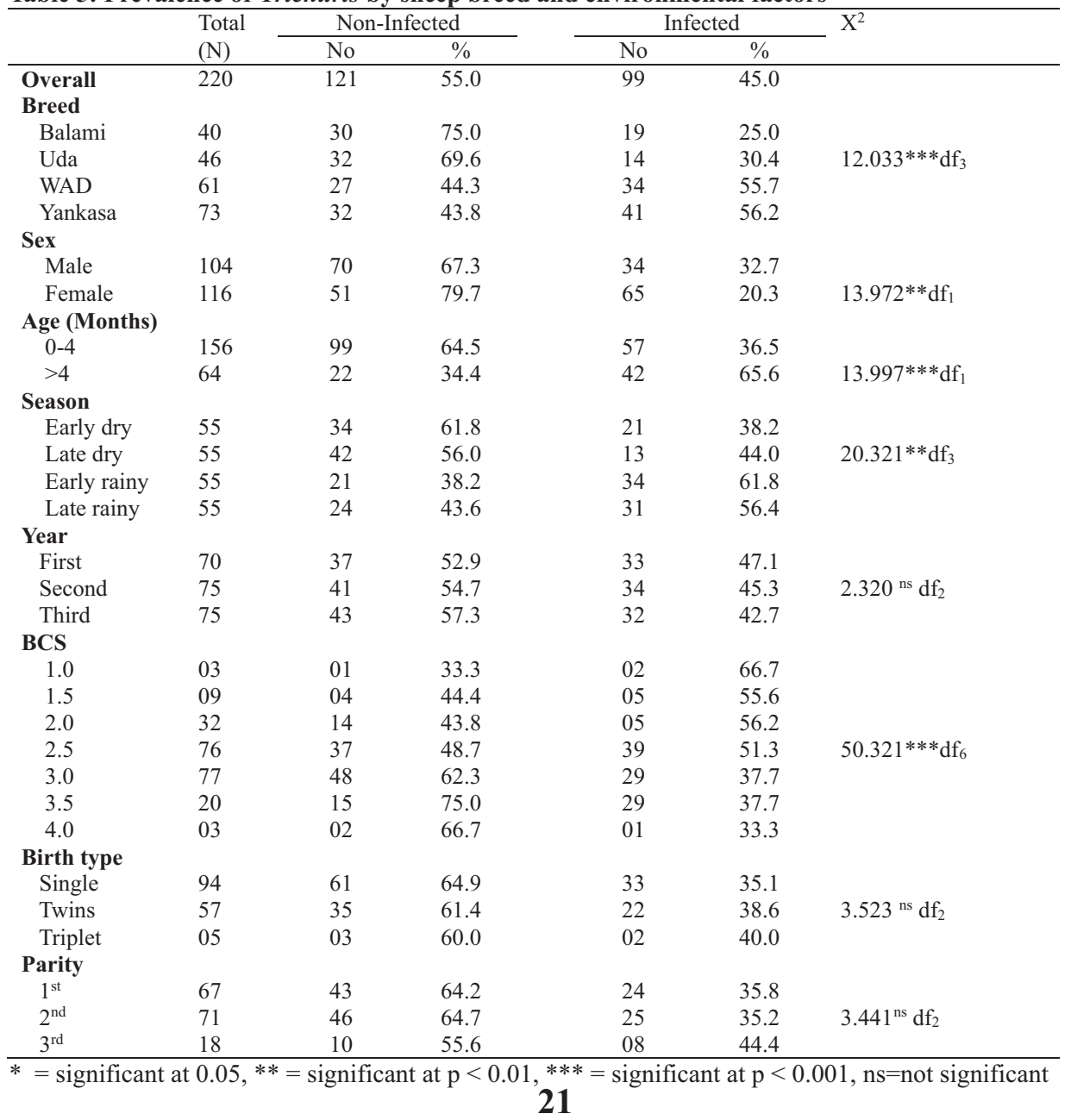




\section{Breed and environmental factors influencing prevalence of helminths in sheep}

\section{Nematodirus prevalence}

The overall Nematodirus prevalence was 46.4\%. Significant $(\mathrm{p}<0.01)$ breed influence on Nematodirus prevalence was observed. Yankasa had the highest prevalence $56.9 \%$ followed by WAD, 53.4\%, Uda, 25.0\% and Balami, 22.5\%. Sex however did not significantly influenced prevalence. The prevalence rates were $48.1 \%$ in male and $44.8 \%$ in females. Age significantly $(\mathrm{p}<0.01)$ influenced prevalence. Adults had higher prevalence $(51.6 \%)$ than lambs with $44.2 \%$. Similarly, significant $(\mathrm{p}<0.01)$ influence of season was observed. The highest prevalence rate of $63.6 \%$ was observed in late rainy season, followed by early rainy $56.4 \%$, early dry, $45.5 \%$ and the least, $20.8 \%$ was in late dry. The yearly prevalence rates of 50.0, 48.0 and $41.3 \%$ respectively in first, second and third did not significantly differ. Body condition score however significantly $(\mathrm{p}<0.001)$ influenced prevalence. Birth type significantly affected prevalence. The highest prevalence rate was observed in singles, 47.9, followed by triplets, 40.0, while twins had the lowest, $38.6 \%$. Prevalence rates were 43.3, 42.9 and $50 \%$ respectively in first, second and third parity lambs. There was no significant difference between them.

Table 6: Prevalence of Nematodirus by sheep breed and environmental factors

\begin{tabular}{|c|c|c|c|c|c|c|}
\hline & \multirow{2}{*}{$\begin{array}{l}\text { Total } \\
(\mathrm{N})\end{array}$} & \multicolumn{2}{|c|}{ Non-Infected } & \multicolumn{2}{|c|}{ Infected } & \multirow[t]{2}{*}{$\mathrm{X}^{2}$} \\
\hline & & No & $\%$ & No & $\%$ & \\
\hline Overall & 220 & 118 & 53.6 & 102 & 46.4 & \\
\hline \multicolumn{7}{|l|}{ Breed } \\
\hline Balami & 40 & 31 & 77.5 & 09 & 22.5 & \multirow{4}{*}{$9.896^{* *} \mathrm{df}_{3}$} \\
\hline Uda & 46 & 30 & 75.0 & 16 & 25.0 & \\
\hline WAD & 61 & 26 & 46.6 & 45 & 53.4 & \\
\hline Yankasa & 73 & 31 & 43.1 & 42 & 56.9 & \\
\hline \multicolumn{7}{|l|}{ Sex } \\
\hline Male & 104 & 54 & 51.9 & 50 & 48.1 & \multirow[b]{2}{*}{$3.897 * * \mathrm{df}_{1}$} \\
\hline Female & 116 & 64 & 55.2 & 52 & 44.8 & \\
\hline \multicolumn{7}{|l|}{ Age (Months) } \\
\hline $0-4$ & 156 & 87 & 55.8 & 69 & 44.2 & \multirow[b]{2}{*}{$12.321 * * \mathrm{df}_{1}$} \\
\hline$>4$ & 64 & 31 & 48.4 & 33 & 51.6 & \\
\hline \multicolumn{7}{|l|}{ Season } \\
\hline Early dry & 55 & 30 & 54.5 & 25 & 45.5 & \multirow{4}{*}{$19.720 * * \mathrm{df}_{3}$} \\
\hline Late dry & 55 & 44 & 80.0 & 11 & 20.8 & \\
\hline Early rainy & 55 & 24 & 43.6 & 31 & 56.4 & \\
\hline Late rainy & 55 & 20 & 36.4 & 35 & 63.6 & \\
\hline \multicolumn{7}{|l|}{ Year } \\
\hline First & 70 & 35 & 50.0 & 35 & 50.0 & \multirow{3}{*}{$2.097^{\mathrm{ns}} \mathrm{df}_{2}$} \\
\hline Second & 75 & 39 & 52.0 & 36 & 48.0 & \\
\hline Third & 75 & 44 & 58.7 & 31 & 41.3 & \\
\hline \multicolumn{7}{|l|}{ BCS } \\
\hline 1.0 & 03 & 01 & 33.3 & 02 & 66.7 & \multirow{7}{*}{$51.332 * * * \mathrm{df}_{6}$} \\
\hline 1.5 & 09 & 01 & 11.1 & 08 & 88.9 & \\
\hline 2.0 & 32 & 13 & 40.6 & 19 & 59.4 & \\
\hline 2.5 & 76 & 41 & 53.9 & 35 & 46.1 & \\
\hline 3.0 & 77 & 45 & 58.4 & 32 & 41.6 & \\
\hline 3.5 & 20 & 14 & 70.0 & 06 & 30.0 & \\
\hline 4.0 & 03 & 03 & 100.0 & 00 & 00.00 & \\
\hline \multicolumn{7}{|l|}{ Birth type } \\
\hline Single & 94 & 49 & 52.1 & 45 & 47.9 & \multirow{3}{*}{$7.897 * \mathrm{df}_{2}$} \\
\hline Twins & 57 & 35 & 61.4 & 22 & 38.6 & \\
\hline Triplet & 05 & 03 & 60.0 & 02 & 40.0 & \\
\hline \multicolumn{7}{|l|}{ Parity } \\
\hline $1^{\text {st }}$ & 67 & 38 & 56.7 & 29 & 43.3 & \multirow{3}{*}{$2.997^{\mathrm{ns}} \mathrm{df}_{2}$} \\
\hline $2^{\text {nd }}$ & 71 & 40 & 57.1 & 31 & 42.9 & \\
\hline $3^{\text {rd }}$ & 18 & 09 & 50.0 & 09 & 50.0 & \\
\hline
\end{tabular}




\section{Dafur, Mbap, Tok and Okoh}

\section{Discussion}

The overall prevalence of gastrointestinal (GI) helminths in the present study is higher than values reported by various workers. Mbap and Chiroma (1998) and Ibukun and Oladunsi (2015) reported an overall prevalence rates of $81.4 \%$ and $82.7 \%$ in Bauchi and Minna, Nigeria, respectively. Alade and Bwale (2015) found an overall prevalence of $60.4 \%$ in Maiduguri, Nigeria. Sangma et al. (2012) reported a value of $81.1 \%$ in Bangladesh. Pandit et al. (2003), Tramboo et al. (2015) reported prevalence rates of $65.4 \%, 62.9 \%$ and $77.00 \%$ respectively in sheep of Kashmir valley, India. Yadav et al. (2006), Khajuria et al. (2013) and Tramboo et al. (2015) reported prevalence rates of 83.24, 68.54 and $77.00 \%$, respectively in sheep of Jammu, India. Moti (2008), Dagnachew et al. (2011), Zerihun (2012) and Diriba and Birhanu (2013) reported overall prevalence rates of $76.3,79.09,59.89$ and $68.1 \%$ respectively from different parts of Ethiopia. Raza et al. (2012) reported overall prevalence of $78.0 \%$ in Pakistan. Lower overall prevalence rates of $53.97 \%$ was reported in Abuja, Nigeria (Solomonwisdom et al. 2014) and 65.5\% in Yankasa sheep in Lafia (Hassan et al., 2013). The overall prevalence rate reported in the present study is highest when compared to most previous reports. This might be due to ecological and management difference and especially as the experimental sheep in this study were never subjected to any form of deworming during the research period. In the current finding, overall Strongyles, prevalence rate predominated those of other species. The predominance of Strongyles infection over other helminth species had been similarly reported. Tramboo et al. (2015) found overall Strongyles prevalence of $60.92 \%$ in Sheep of Kashir valley, India which was predominant over Moniezia (7.92\%), Strongloides (1.67\%) and Trichuris
(1.50\%). Shahnawaz et al. (2011) reported overall cestode prevalence of $11.68 \%$ in sheep in Ganderbal district of Kashmir valley. Tariq et al. (2008) also reported overall $61.6 \%$ nemathelminths prevalence in sheep of Kashmir valley. The predominance of Strongyles over other nematodes and cestodes in sheep have similarly been reported by Pandit et al. (2003) and Wani et al. (2011) in Kashmir valley; Khajuria and Kapoor (2003) and Yadav et al. (2006) in sheep of Jammu region, India; Raza et al. (2014) in sheep of Chodist desert of Pakistan and Ibukun and Oludunsi (2015) in Minna, Nigeria; That overall helminths prevalence in this study ranked breeds in the following order: Yankasa, WAD, Balami, and Uda from the highest to lowest. This differs from the finding of Thlama et al. (2016) in Maiduguri, Nigeria. These authors found highest prevalence in Uda $(100 \%)$ followed by Yankasa (77.1\%) while Balami (66.7\%) was least. Dafur (2008b) reported that Yankasa had highest prevalence followed by Uda and Balami under communal management system on the Jos Plateau. However, these reports contradict that of Mbap and Chiroma (1996) who found no significant difference in helminths prevalence among Yankasa, Uda and Balami sheep in Bauchi. Difference in findings could be due to ecology, climate and management practices (Dafur et al., 2008a).

\section{Sex}

Significant influence of sex on prevalence with females exhibiting higher values than males in this study agrees with previous studies. Higher prevalence in female than male sheep had been reported in Maiduguri (Thlama et al., 2016), Abuja (SolomonWisdom et al., 2014), Bauchi (Mbap and Chiroma, 1998), and Jos (Dafur et al., 2008b) in Nigeria. Similar finding was recorded in Pakistan (Raza et al., 2014). However, the present finding contravenes 


\section{Breed and environmental factors influencing prevalence of helminths in sheep}

the report of Hassan et al. (2013) and Ibukun and Oludunsi (2015) in Nigeria and Gatachew et al. (2017) in Ethiopia who all found non-significant difference between sex in helminth prevalence.

\section{Age}

The significantly higher prevalence of total helminths, Strongyles, Strongyloides, Moniezia, Trichuris and Nematodirus observed in adult sheep than suckling lambs are in consonance with the reports of various workers. Thlama et al. (2016) found higher prevalence of all parasites species, cestodes and strongyles in adult than young sheep (with respective values of 82.4 vs $65.8 \%, 2.1$ vs $0.0 \%$ and 36.0 vs $17.1 \%$ ) in Maiduguri, Nigeria. Similarly, Hassan et al. (2013) found significantly lowest prevalence $(2.1 \%)$ in lamb $(<6$ months old) as compared to 6-12 months (28.7\%) and above 12 months (34.7\%) in Yankasa sheep in Lafia, Nigeria. Tramboo et al. (2015) recorded significantly higher prevalence of all gastrointestinal helminths in adults ( $>1$ year, $83.00 \%)$ than lambs and hoggets ( $\leq 1$ year, $53.11 \%$ ) in sheep of Kashmir valley, India. The authors further reported higher prevalence rates of trematodes and nemathelminths in adults than young sheep. Other workers, Swarnkar et al. (1996) and Yadav et al. (2006) similarly reported higher helminths prevalence in adults than young sheep. Tramboo et al. (2015) however observed lower Moniezia prevalence in adult than young sheep. Other reports of higher prevalence in young than adult sheep include (Pal and Qayyum, 1992; Getachew et al., 2017). Mbap and Chiroma (1998) on the other hand did not find any significant difference between age groups in helminths prevalence.

\section{Body condition score}

In the present study, BCS was observed to affect prevalence of gastrointestinal (GI) helminths, especially in animals with lower $\mathrm{BCS}$ values. This is in agreement with some previous reports. Thlama et al. (2016) found higher prevalence of GI parasites and Strongyles in emaciated and thin sheep in Maiduguri as compared to those with average BCS. Getachew et al. (2017) also found highest prevalence in sheep with poor BCS $(73.1 \%)$ in Ethiopia compared to the ones with medium BCS (52.6\%) and good BCS $(37.5 \%)$. The lower prevalence of helminths in sheep with good BCS could be due to better immunity. It may also signify the importance of parasites in causing weight loss (Urquhart et al., 1996; Radostits et al., 2007).

\section{Season}

Influence of season on prevalence of parasites as seen in the present study especially in wet than dry seasons have similarly been documented by several researchers (Swarnkar et al., 1996; Dafur et al., 2008b; Tramboo et al., 2015). Dafur et al. (2008b) observed generally higher prevalence of GI helminths in rainy than dry season in sheep under communal management on the Jos plateau, Nigeria. Tramboo et al. (2015) observed higher prevalence in summer followed by spring, autumn while winter was least in Kashmir valley sheep of India. Swarnkar et al. (1996) earlier observed peak parasitism in summer under semi-arid conditions. Tramboo et al. (2015) suggested that the highest rates of infection in summer was due to favourable environmental condition for hatching and development of free-living larval stages. Okon and Enyenihi (1977) and Umoh et al. (1982) also suggested that rainfall is one of the epizootiological factors that favour egg and larval development. Gibbs (1982) stated that the most suitable factors that determine larval survival on pasture are temperature, moisture and rainfall.

\section{Year, parity and birth type}

Year, dam's parity and lamb's birth type did not influence helminthosis prevalence in the present study. This could be due to 


\section{Dafur, Mbap, Tok and Okoh}

similarities in environmental conditions and management practices. Non-significant higher prevalence was also observed by Ibukun and Oludunsi (2015) in the year 2013 (84.0\%) and 2012 (81.2\%) in Minna, Nigeria.

\section{Conclusions and recommendations}

In conclusion, there was high helminth prevalence in the study area. Nigerian sheep breeds vary in susceptibility to helminthosis with Yankasa and WAD being more susceptible compared to Balami and Uda. Helminth infections are higher in female and older sheep than males and suckling lambs respectively. Helminth infection is higher in wet than dry season. Breed variation in prevalence to helminthosis should be exploited through selection and cross breeding to control the disease without or with minimal use of anthelminthics. Greater attention should be paid to older sheep ( $\geq 4$ months), females and rainy seasons in worm control.

\section{References}

Adegbola, T. A. 1998. Sustainable ruminant production for human nutrition and national development. Inaugural Lecture Series No. 7 Abubakar Tafawa Balewa University, Bauchi held on 21st January 1998.

Ajala, M. K., Lamidi, O. S. and Otaru, S. M. 2008. Peri-urban small ruminant production in Northern Guinea Savanna, Nigeria. Asian Journal of Animal and Veterinary Advances, 3:138-146

Akerejola, O. O., Schillhom Van Veen, T. W. and Njoku, O. O. 1979. Ovine and Caprine disease in Nigeria: A review of economics losses. Bulletin of Animal Health and Production in Africa, 27: 6570.

Alade, N. K. and Bwale, M. D. 2015. Gastrointestinal-parasites infestation in Yankasa sheep in a semi-arid environment. Livestock Research for Rural Development, 27:106-114

Alrifai, M. 2010. Faecal egg countingModified Mcmaster Technique. Accessed December 30, 2011, from: www.scribd.com/user/9889064/Ah med Alrifai

Anonymoūs. 1990. Introduction to breeds of sheep in Nigeria. Extension Guide No. 149. Livestock series No. 24 NAERELS A.B.U. Zaria.

Baker, R. L., Mugambi, J. M., Audho, J. O., Carles, A. B. and Thorpe, W. 2004. Genotype by environment interactions for productivity and resistance to gastro-intestinal nematode parasites in Red Maasai and Dorper sheep. Animal Science, 79: 343-353.

Barger, L. A. 1982. Helminth parasites and animal production. In: Biology and Control of Endo-parasites A. E. A. Symons, A. D. Donald, J. K. Dineen, (Eds). Academic Press, Sydney, Australia pp. 133155.

Biu, A. A., Maimunatu, A., Salamatu, A. F. and Agbadu, E. T. 2009. A faecal survey of gastrointestinal parasites of ruminants on the University of Maiduguri Research Farm. International Journal of Biomedical Health Science, 5(4): 175-179.

Charon, K. M. 2004. Genes controlling resistance to gastrointestinal nematodes in ruminants. Animal Science Papers and Reports, 22 (1): 135139.

Chiroma, B. Y. 1996 Breed and environmental factors on worm infection in sheep at Bauchi Railway Livestock Market. B. Agric Tech (Hons). Dissertation, Abubakar Tafawa Balewa University, Bauchi.

Courtney, C. H., Parker, C. F., Mclure, K. B. and Herd, R. P. 1984. A 


\section{Breed and environmental factors influencing prevalence of helminths in sheep}

comparison of the peripanurient rise in laecal egg counts of exotic and domestic ewes. International Journal of Parasitology, 14: 377 381.

Dafur, B. S., Mbap, S. T and Butswat, I. S. R. 2008a. Seasonal Pattern of Sheep helminthiasis on the Jos Plateau. Journal of the League of Research in Nigeria, 9 (1): 10-14.

Dafur, B. S., Mbap, S. T. and Butswat, I. S. R.2008b. Differential sheep breed resistance to helminthiasis on the Jos Plateau. Proceedings of $13^{\text {th }}$ Annual conference of the Animal Science Association of Nigeria (ASAN), September $15-19^{\text {th }}$, ABU Zaria. Pp 675-678.

Dagnachew, S., Amamute, A. and Temegen, W. 2011. Epidemiology of gastrointestinal helminthiasis of small ruminants in selected sites of North Gondar zone, Northwest Ethiopia. Ethiopia Veterinary Journal 15: 57-68.

Diriba, L. and Birhanu, A. 2013. Prevalence of ovine gastrointestinal nematodes in and around Asella, South Eastern Ethiopia. Journal of Veterinary Medicine and Animal Health 5: 222-228.

Gamble, H. R. and Zajac, A. M. 1992. Resistance of St. Croix lambs to Haemonchus contort us in experimentally and naturally acquired infections. Veterinary Parasitology 41:211-225.

Getachew. M., Tesfaye, R., Sisay, E. 2017. Prevalence and Risk Factors of Gastrointestinal Nematodes Infections in Small Ruminants in Tullo District, Western Harerghe, Ethiopia. Journal of Veterinary Science and Technology, 8: 428.

Gibbs, H. Q. 1982. Mechanism of survival of nematode parasites with emphasis on hypobiosis. Veterinary parasitology, 11:25- 48.

Hassan, D. I., Mbap. S. T and Naibi, S. A. 2013. Prevalence of worm infection in Yankasa sheep and West African dwarf goats in Lafia Town and Environs, Nigeria. Journal of Agriculture and Veterinary Science, 4: 84-90.

Ibukun, A. V. and Oludunsin, F. O. 2015. Prevalence of intestinal helminths and protozoa parasites of ruminants in Minna, North Central, Nigeria. Journal of Agriculture and Veterinary Science, 8(11): 62-67.

Kassai, T. 1999. Veterinary Helminthology. Oxford UK: Butterworth Heinemann

Khajuria, J. K. and Kapoor, P. R. 2003. Prevalence of parasites in sheep and goats at Kathua-Jammu. Journal of Veterinary Parasitology, 17: 121126.

Kloosterman, A., Pamientier, H. K. and Ploeger, H. W. 1992. Breeding cattle and sheep for resistance to gastrointestinal nematodes. Parasitology Today 8: 330-335.

Knight, R. A., Vegors, H. H., \& Lindahl, I. L. 1973. The Epidemology of parasitic diseases with special reference to studies with nametode parasites of sheep. Journal of Parasitology, 58, 12 - 16.

ILCA. 1992. Genetic resistance to gastrointestinal parasitism in small ruminants. 1LCA project proposal 2.2 /0102/01.

Mbap, S. T. And Chiroma, B. Y. 1996. The effects of breed and environmental factors on helminth infection of sheep in Bauchi, Nigeria. In: Proceedings of the 6th World Congress on Genetics Applied to Livestock Production. Armidale, NSW, Australia, 25:261-264.

Moti, W. 2008. Prevalence of gastrointestinal nematode of sheep and goats in and around Welinchity, 


\section{Dafur, Mbap, Tok and Okoh}

Central Ethiopia. DVM Thesis, HU, FVM, Haramaya, Ethiopia.

Okon, E. D. and Enyenihi, U. I. 1977. Development and survival of Haemonchus contortus larvae on pasture in Ibadan. Tropical Animal Health and Production, 9: 7-10.

Oni, O. O. 2002. Breeds and generic improvement of small ruminants. Small ruminant production training workshop. National Animal Production Research institute, Ahmadu Bello University, ShikaZaria, PP: 1-7.

Orokpo, J.A. 1991. The effect of breed and environmental factors on worm infection of sheep at Oscar Farm. B. Agric Tech. (Hons). Dissertation; Abubakar Tafawa Balewa University, Bauchi, Nigeria.

Pal, R. A. and Qayyum, M. 1992. Breed, age and sex wise distribution of gastrointestinal helminthes of sheep and goats in and around Rawalpindi region. Pakistan Veterinary Journal 12(2): 6068.

Pandit, B. A., Shahardar, R. A., Darzi, M. M., Banday, M. A. A. and Bhat, A. S. 2003. Survey of gastrointestinal nematodes in sheep of Kashmir Valley. Indian Journal of Small Ruminants, 9:39-42.

Pollot, G. E. and Greeff, J. C. 2004. Genetic relationships between faecal egg count and production traits in commercial Merino sheep flocks. Animal Science, 79:2132.

Preston, J. M. and Allonby, E. W. 1978. The influence of breed on the susceptibility of sheep and goats to a single experimental infection with Haemonchus contortus. Veterinary Record, 103: 509-512.

Radostits, O. M., Gay. C. C., Hinchcliff, K. W., and Constable, P. D. 2007. Veterinary Medicine: A textbook of the diseases of cattle, horses, sheep, pigs and goats. 10th eds., Saunders Ltd, London, UK.

Raza, M. A., Murtaza, H. A. Bachaya, H. M. Arshad, M. Naeem, S. and Kazmi, H. F. 2012. Predominance of gastrointestinal helminthiasis in Ovis aries (sheep) at the vicinity of Jatoi. Pakistan International Science, 24: 289-292.

Sangma, A., Begum, N., Roy, B. C. and Gani, M. O. 2012. Prevalence of helminth parasites in sheep (Ovis aries) in Tangail district, Bangladesh. Journal of Bangladesh Agricultural University, 10 (2): 235 244.

Sastry, N. S. R and Thomas, C. K. 1980. Farm Animal Management. 2nd edition, PVT limited London. 42 pp.

Schillhom Van Veen, T. W. 1973. Small ruminants health problem in nonhem Nigeria with emphasis on helminthiasis. Nigeria Veterinary Journal, 2: 26-31.

Shahnawaz, M., Shahardar, R. A. and Wani, Z. A. 2011. Seasonal prevalence of platyhelminthosis of sheep in Ganderbal area of Kashmir Valley Journal of Veterinary Parasitology, 25: 59-62.

Smith, S. M. 2002. AGRl-Focus July 2002. Cooperative extension, Washington state University, Grant and Adams Area. Retrieved April 13, 2002, from: http://grant-adams.wsu.edu.

Solomon-Wisdom, G. O., Matur, B. M. and Ibe, K. C. 2014. Prevalence of intestinal helminth infection among sheep and goats raised for slaughtered in Gwagwalada Abattoir, Abuja Nigeria. Journal of Global Pharmaceutical Sciences, 2(1): 1219.

Steel, R. G. D. and Torrie, J. H. 1980. Principles and Procedures of Statistics. $2^{\text {nd }}$ Edition. McGraw-Hill 
Breed and environmental factors influencing prevalence of helminths in sheep

(New York), pp. 633.

Swarnkar, C. P., Singh, D., Srivastava, C. P., Bhagwan, P. S. K. and Dimri, U. 1996. A restrospective study on ovine gastrointestinal helminthoses under semi - arid conditions. Journal of Veterinary Parasitology, 10: 15-21.

Tariq, K. A., Chisti, M.Z., Ahmad, F. and Shawl, A. S. 2008. Epidemiology of gastrointestinal nematodes of sheep managed under traditional husbandry system in Kashmir Valley. Journal of Veterinary Parasitology, 158(1-2): 138-143

Thlama, P. B., Abdullahi, A. B., Ahmed, G. M., Mohammed, A., Philip, M. H. and Yusuf, J. 2016. Point Prevalence and Intensity of Gastrointestinal Parasite Ova/Oocyst and Its Association with Body Condition Score (BCS) of Sheep and Goats in Maiduguri, Nigeria. The Journal of Advances in Parasitology, 3(3): 81-88.

Thompson, J. and Meyer, H. I. 1994. Body condition scoring of sheep. Oregon State University Extension Service, U.S.A.

Tramboo, S. R., Shahardar, R. A. I., Allaie, M., Wani, Z. A. and Bushra, M. S. 2015. Prevalence of gastrointestinal helminth infections in ovine population of Kashmir Valley. Veterinary World, 8:11911204.
Umoh, J. U., Shaibu, Y. and Akerejola, O. O. 1982. Gastrointestinal Parasitism in clinical cases of small ruminants in Zaria, Nigeria. Bulletin for Animal Health and Production in Africa. 30: 111-116.

Urquhart, G. M., Armour, C. D., Duncan, J. L., Dunn, A. M. and Jennings, F. W. 1996. Veterinary Parasitology. $2^{\text {nd }}$ edition. Blackwell Science Ltd. Australia, 195 pp.

Wani, Z. A., Shahardar, R. A. and Shahnawaz, M. 2011. Prevalence of nemathelminth parasites in sheep of Ganderbal district of Kashmir Valley. Journal of Veterinary Parasitology, 25(1): 26-29.

Yadav, A., Khajuria, J. K. and Raina, A. K. 2006. Seasonal prevalence of gastrointestinal parasites in sheep and goats of Jammu. Journal of Veterinary Parasitology, 20(1): 6568

Zerihun, T. 2012. Helminthosis of sheep and goats in and around Haramaya, Southeastern Ethiopia. Journal of Veterinary Medicine and Animal Health 4: 48-55.

Recieved: $20^{\text {th }}$ August, 2020 Accepted: $21^{\text {st }}$ November, 2020 